\title{
A New Form of Arthritis Mutilans Related to Successful Gout Treatment
} Kristin Sigurjonsdottir and Helgi Jonsson*

Department of Rheumatology, Landspitalinn University Hospital, University of Iceland, Iceland

*Corresponding author: Helgi Jonsson, Department of Rheumatology, Landspitalinn University Hospital, University of Iceland, 101 , Iceland, Tel: +354 525 4000; E-mail: helgijon@landspitali.is

Received date: June 29, 2018; Accepted date: June 29, 2018; Published date: June 30, 2018

Copyright: (c) 2018 Sigurjonsdottir K, et al. This is an open-access article distributed under the terms of the Creative Commons Attribution License, which permits unrestricted use, distribution, and reproduction in any medium, provided the original author and source are credited.

Citation: Sigurjonsdottir K, Jonsson H (2018) A New Form of Arthritis Mutilans Related to Successful Gout Treatment. J Arthritis 7: i107. doi: 10.4172/2167-7921.1000i107

\section{Clinical Image}

82 years old woman with a history of severe nodal hand osteoarthritis affecting both fingers and thumb base. She also had hypertension and chronic renal failure and in 1992 she started getting attacks of gout. Attempts to treat her with allopurinol had to be stopped due to side effects. Her hands became progressively affected by tophaceous gout with chronic pain particularly in the DIP joints. In 2012 she started febuxostat $80 \mathrm{mg}$ daily. Her symptoms improved within weeks and serum uric acid levels changed from $712 \mu \mathrm{mol} / \mathrm{l}$ in 2012 to $89 \mu \mathrm{mol} / \mathrm{l}$ in 2014. Tophy at other sites, including a large olecranon tophus regressed and have now disappeared (Figure 1).

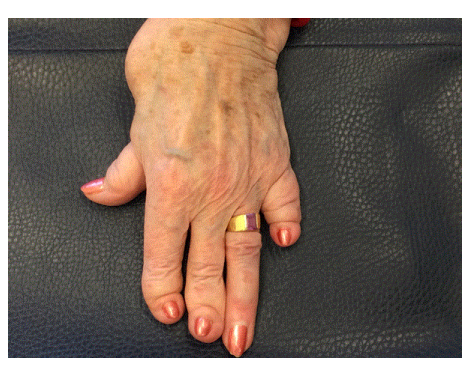

Figure 1: Hand osteoarthritis.
Looking at her hands today it is surprising that she is quite satisfied with her treatment. Despite the deformities, the hands are now totally painless. Apparently, her DIP joints and phalanges were so saturated with uric acid deposition that when the trophy resorbed the bones collapsed. 